\title{
Germinal tumor invasion and the role of the testicular stroma
}

\author{
ALEJANDRO DÍEZ-TORRE ${ }^{1}$, UNAI SILVÁN ${ }^{1}$, OLIVIER DE WEVER ${ }^{2}$, ERIK BRUYNEEL ${ }^{2}$, MARC MAREEL $^{2}$ \\ and JUAN ARÉCHAGA ${ }^{1}$ \\ ${ }^{1}$ Department of Cell Biology and Histology, School of Medicine and Dentistry, University of the Basque Country, Leioa, Vizcaya, Spain and \\ ${ }^{2}$ Laboratory of Experimental Cancerology, Department of Radiotherapy and Nuclear Medicine, Ghent University Hospital, Ghent, Belgium
}

\begin{abstract}
Testicular germ cell tumors (TGCTs) are the most frequent neoplasia among young people and their incidence has grown very quickly during recent decades in North America and Europe. Many studies have been carried out in order to elucidate the factors involved in the appearance and progression of these tumors. Little is known about the role of cancer cell-stroma crosstalk in TGCT invasive processes. Here, we review several factors which may be implicated in germ cell tumor progression, such as matrix metalloproteinases, insulin-like growth factor, transforming growth factor beta, the cadherin/catenin complex and integrins. Paradoxically, some of these molecules are also involved in the regulation of normal testicular function. Finally, we discuss prospects for future research on the role of the stroma in the progression and differentiation of male germ cell tumors.
\end{abstract}

KEY WORDS: germinal tumor, embryonal carcinoma, teratocarcinoma, ES, EG, stroma-cell interaction

\section{Introduction}

In order to invade surrounding tissues and produce metastasis, cancer cells detach from the primary tumor, break through the basement membrane and reach the circulation. Cell-cell and cellmatrix adhesion molecule alterations, motility factors and degradation of extracellular matrix (ECM) by proteolytic enzymes are needed for these processes. Recent advances in cancer research have highlighted the important role of the cancer-stroma interaction in the regulation of invasive processes. However, very little is known about the role of the stroma in testicular germ cell tumor invasion. The aim of this paper is to review current knowledge about factors involved in tumor invasion in general and the possible role of the testicular stroma in the case of germinal tumors of the testis.

Mouse seminiferous tubules are isolated from the stroma by a monolayer of peritubular myoid cells with basement membrane on both sides. Many cell types are present in the stromal compartment of the testis, including Leydig cells, which are the most abundant and constitute a specific cell population. The main function of Leydig cells is the synthesis of testosterone, which among other things stimulates spermatogenesis. Histopathology of testicular germ cell tumors frequently reveals the proliferation of both myoid cells and Leydig cells, which suggests a possible implication of these cells in tumor progression; new blood vessel formation has also been observed. In the testicular stroma other cell types are present, such as fibroblasts, macrophages, mast cells, lymphocytes and endothelial cells. Each of these may play a role in germ cell tumor invasion, as they do in other kinds of tumors, by secreting proteolytic enzymes, by triggering pro-invasive signals or by facilitating the extravasation of cancer cells to the circulation (Fig. 1).

Testicular germ cell tumors (TGCTs) represent $95 \%$ of testicular neoplasias, but only $\sim 2 \%$ of all cancers in males. Histologically they can be classified as seminomas which are made up of undifferentiated germ cells, and non-seminomas which are made up of undifferentiated multipotent cells (embryonal carcinoma) and derived differentiated populations. Examples of the latter include embryoid bodies and/or other more differentiated tissues com-

\footnotetext{
Abbreviations used in this paper: dbcAMP, dibutyryl cyclic AMP; EC, embryonal carcinoma;ECM, extracellular matrix; EG, embryonic germ;EGF, epidermal growth factor; bFGF, basic fibroblast growth factor; FSH, follicle stimulating hormone; GH, growth hormone; IGF, insulin-like growth factor; IL, interleukin; LH, luteinizing hormone; MMP, matrix metalloproteinase; PDGF, platelet derived growth factor; PGC, primordial germ cell; SF/HGF, scatter factor/hepatocyte growth factor; TGCT, testicular germ cell tumor; TGF- $\beta$, transforming growth factor $\beta$; TIMP, tissue inhibitors of metalloproteinases.
} 


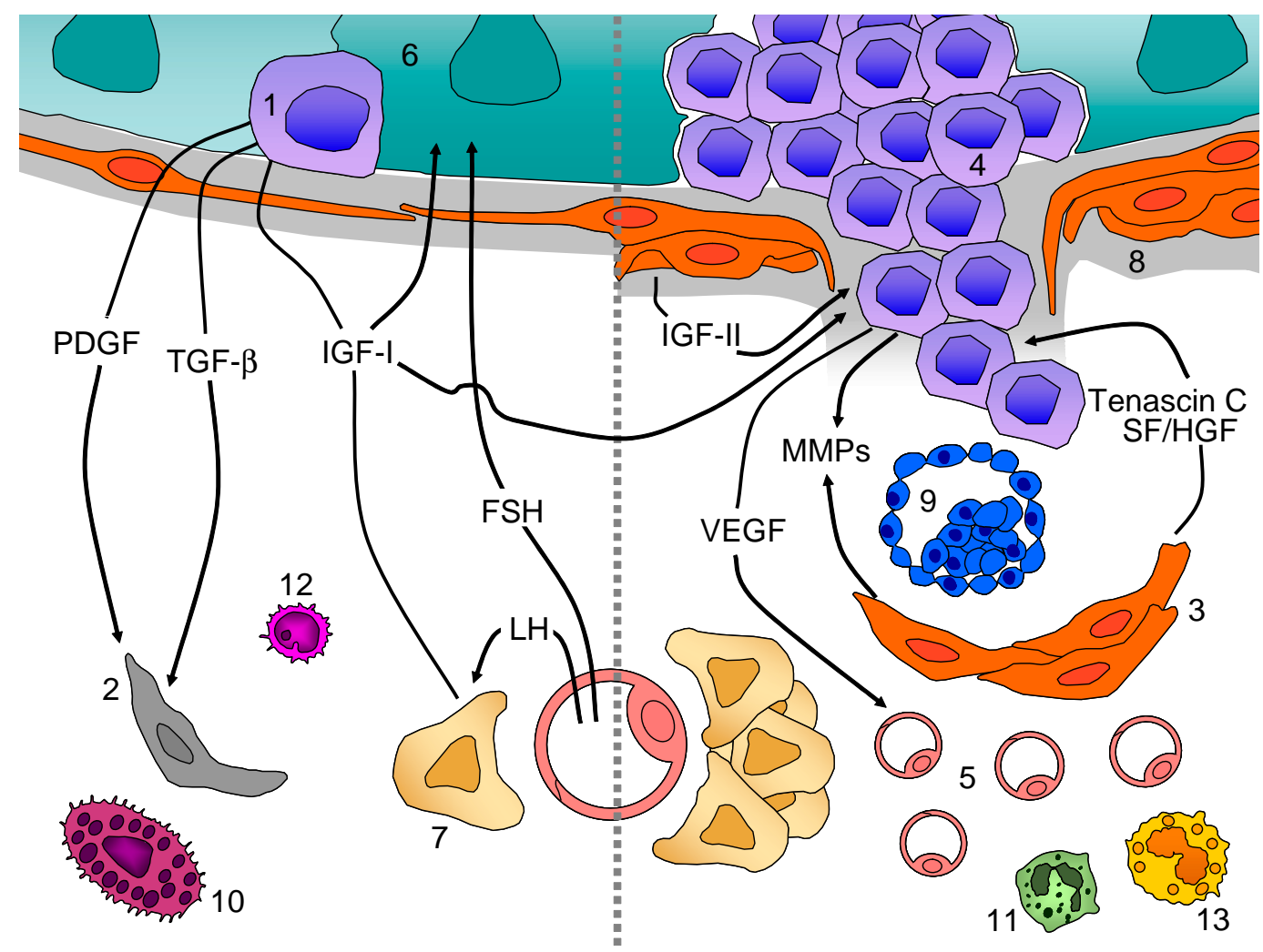

Fig. 1. Cellular interactions and factors potentially involved in the transition from in situ (left) to invasive embryonal carcinoma of the testis (right). Carcinoma-insitu cells (1) secrete growth factors which may acts on the stroma, such as TGF- $\beta$ and PDGF. The former acts as a chemoattractant of fibroblasts (2) and induces their transdifferentiation to myofibroblasts (3), while PDGF stimulates the proliferation of both fibroblasts and myofibroblasts. The myofibroblasts concentrated next to the intratubular carcinoma-in-situ produce proinvasive factors such as MMPs, SF/HGF and tenascin C which may contribute to the progression of carcinoma-in-situ to invasive germ cell tumor (4). In the invasive cells there is an upregulation of the oncogene ets1 which enhances the expression of proangiogenic factors such as SF/HGF and VEGF which induce new blood vessel formation (5) needed for metastasis. IGF-I is synthesized by carcinoma-in-situ cells, Sertoli cells (6) and Leydig cells (7) and its production is en-

hanced in the last two populations by the hormones FSH and LH respectively. IGF-I increases lactate synthesis and glucose transport in Sertoli cells, facilitating germ cell support. IGF-I may also contribute to germ cell tumor progression stimulating MMP synthesis in carcinoma cells, protecting against apoptosis and promoting cell migration. On the other hand, IGF-II, produced mainly in the peritubular stroma (8), enhances spermatogonia proliferation. Once in the stromal compartment, embryonal carcinoma cells undergo differentiation and may produce blastocyst-like structures, the so-called embryoid bodies (9) and other differentiated tissues (teratocarcinoma, choriocarcinoma, yold sac tumor). The proliferation of Leydig cells and peritubular myoid cells is a common observation in germ cell tumor histopathology. The inflammatory process associated with embryonal carcinoma invasion increases the size of certain populations of cells of the immune system such as mast cells (10), polymorphonuclear leukocytes (11), lymphocytes (12) and macrophages (13).

posed of somatic (teratocarcinoma), trophoblastic (choriocarcinoma) or endodermic (yolk sac tumor) cells. However, although their histogenesis is a matter of debate (Damjanov, 1991), both tumors have as a common precursor the carcinoma-in-situ of the testis, which is derived from primordial germ cells (PGCs) at early stages of embryonic development (Skakkebaek et al., 1987; Jorgensen et al., 1995). At birth, there are a low number of carcinoma-in-situ cells in the seminiferous tubules which remain latent till puberty, when they begin spreading along the basement membrane of the germinal epithelium, probably due to the increase in the levels of sexual hormones. The factors which trigger the transition from carcinoma-in-situ to invasive tumor (Fig. 1) can be both genetic and environmental in nature. The genetic alteration most clearly involved in this progression is the overrepresentation of the short arm of chromosome 12 (Roelofs et al., 2000; Looijenga et al., 2003), present in the invasive and adjacent cells, but not in early stages of carcinoma-in-situ. This suggests that genes in this region could be involved in tumor progression. One of these genes is the Defender against Apoptotic Death-Relatedgene (DAD-R), whose function is not yet known. However, its homologous gene Defender against Apoptotic Death-1 (DAD-1) has been shown to be associated with protection against apoptosis (Zafarana et al.,
2002). Among testicular tumors, embryonal carcinoma is one of the most aggressive because of its high metastatic potential. It produces small tumors of heterogeneous appearance and maintains its ability to differentiate into other pathological variants, which include embryonal (in teratomas and teratocarcinomas) and extraembryonal (trophoblast and yolk sac) tissues. Because of the morphological and biochemical similarities between embryonal carcinoma and embryonic stem cells, such as their ability to differentiate into tissues derived from the three germ layers, they have become frequently used as models in stem cell differentiation studies.

In the middle of the 20th century the teratocarcinoma, whose stem cells are embryonal carcinoma cells, became a very important research model in Embryology. Embryonal carcinoma cells were isolated from both spontaneous (Kahan and Ephrussi, 1970) and experimentally induced teratocarcinomas (Evans, 1972; Berstine et al., 1973). The experimental induction of these tumors was achieved by means of transplantation of gonadal ridges or whole embryos, up to 12.5 days post coitum, into extra-uterine sites, such as the kidney capsule (Solter et al., 1970) or testis (Stevens, 1970). The germinal origin of teratocarcinomas was demonstrated using these techniques (Stevens, 1970). Nowadays 
many embryonal carcinoma cell lines are available. The F9 cell line is one of them which was isolated from the teratocarcinoma OTT6050 (Berstine et al., 1973), which in turn was generated by the transplantation of a 6 day embryo into a 129/Sv strain mouse testis, a mouse strain which has a high incidence of spontaneous teratomas and, much less frequently, teratocarcinomas (Stevens and Hummel, 1957; Jiang and Nadeau, 2001). Because F9 is a nullipotent cell line which shares many characteristics with cells of the early embryos, it is an appropriate model for studying the molecular mechanisms of differentiation (Lehtonen et al., 1989; Alonso et al., 1991). P19 is another embryonal carcinoma cell line, isolated from an experimental teratocarcinoma induced in the $\mathrm{C} 3 \mathrm{H} / \mathrm{He}$ mouse strain (McBurney and Rogers, 1982; McBurney, 1993) and characterized by its capacity to differentiate into the three germ layer-derived tissues. Human embryonal carcinoma cell lines have also been isolated, for example Ntera-2 (Andrews et al., 1984).

Whereas seminomas are functionally equivalent to PGCs, nonseminomas, such as embryonal carcinoma, are more similar to embryonic stem cells (Oosterhuis and Looijenga, 2003). Embryonic stem cell lines can be obtained from the inner cell mass of preimplanted blastocysts and cultured on a feeder layer of fibroblasts (Evans and Kaufman, 1981). In this way, cell colonies can be maintained undifferentiated in culture for a long time. The AB1 cell line was produced by this technique. On the other hand, embryonic germ cell lines have been obtained directly from PGCs cultured in vitro. The EG-1 cell line, for example, was obtained from PGCs of 129/Sv mouse embryos (Steward et al., 1994).

\section{Matrix metalloproteinases}

Proteinases play an essential role in tumor invasion, taking part in several steps of the metastatic process, such as angiogenesis, local invasion or the intra- and extravasation, into or from the circulation. The proteinases involved in these processes include cathepsins (Thorpe et al., 1989), plasminogen activators (Duffy et al., 1988) and matrix metalloproteinases (MMPs; Folgueras et al., 2004). Recently, the role of MMPs as mediators of the cancer-host interaction has been reviewed (Lynch and Matrisian, 2002). The MMPs constitute a family of zinc-dependent endopeptidases, the majority of which appear in the form of latent pro-enzymes which need the proteolytic degradation of a pro-domain to become active. The MMPs can be secreted, although they need to be tethered close to the membrane by specific receptors to have focused proteolytic activity, or appear associated to the membrane by means of a transmembrane domain. Depending on their substrate preference they are classified into collagenases, gelatinases, stromelysins and membrane type MMPs (MT-MMPs).

Cancer cells were considered to be the main producers of proteinases, responsible for the degradation of the ECM during invasion. In fact, the first immunohistochemistry experiments on breast carcinoma showed that MMP-2 was present in cancer cells at the invasion front (Barsky et al., 1993). Protease expression by cancer cells has also been observed in in vitroinvasion assays with collagen type I and Matrigel (reconstituted basement membrane) as substrates. For example, we recently observed that the invasive capacity of the murine embryonal carcinoma P19 cells in Matrigel decreased by $80 \%$ when treated with a protease inhibitory mixture consisting of galardin, aprotinin and leupeptin (data not shown).
Using gelatin zymography, we observed pro-MMP-2 expression in the cell lines P19 and F9, in the human embryonal carcinoma cell line Ntera-2, in the mouse embryonic stem cell line $A B 1$ and in the embryonic germ cell line EG-1. In the case of P19 and AB-1, the expression of pro-MMP-9 was also detected, but at a much lower level than that of pro-MMP-2. In contrast, the Ntera-2 cell line was found to express both the pro-MMP-2 and pro-MMP-9 proteinases at similar levels and it is the only one which produces the active form of MMP-2 (Fig. 2).

The main role of cancer cells in the secretion of proteinases was reconsidered when it was shown by hybridization techniques that stroma cells are the main source of MMPs. Several papers showed that MMP transcripts appear mostly in stromal cells (Okada et al., 1995; Heppner et al., 1996; Uria et al., 1997). MMP-11, for instance, has been localized specifically in breast tumor associated fibroblasts, but not in normal breast fibroblasts (Basset et al., 1990). MMP-7 is an exception as it is a unique MMP which seems to be expressed preferentially by cancer cells in most cases. We did not detect expression of MMP-7 (matrilysin) in F9 or P19 embryonal carcinoma cell lines using casein zymography (data not shown). Distinct works have demonstrated that MMP-7 expression by cancer cells requires them to interact with surrounding stromal cells (Bair et al., 2001).

Therefore the proteolytic process is achieved jointly by cancer cells and stromal cells. One example is proMMP-2 derived from fibroblasts, which is activated by the MT1-MMP/TIMP-2 complex present in the membrane of carcinoma cells (Strongin et al., 1995; Sato et al., 1999; Mitra et al., 2003), hence facilitating cancer invasion, although others mechanisms have been proposed for MMP-2 activity on the cancer cell surface (Emmert-Buck et al., 1995; Brooks et al., 1996). It has been observed recently that the levels of proMMP-2, MT1-MMP and TIMP-2 in rat Sertoli cells in culture are increased by treatment with follicle-stimulating hormone (FSH) (Slongo et al., 2002). It is also known that the expression of proMMP-2 in peritubular myoid cells is about 25folder higher than that of Sertoli cells in culture. This suggests that myoid cells provide pro-invasive information by the secretion of proteinases. This secretion is upregulated by concanavalin $A$, dibutyryl cyclic AMP (dbcAMP) and IL-1 (Hoeben et al., 1996).

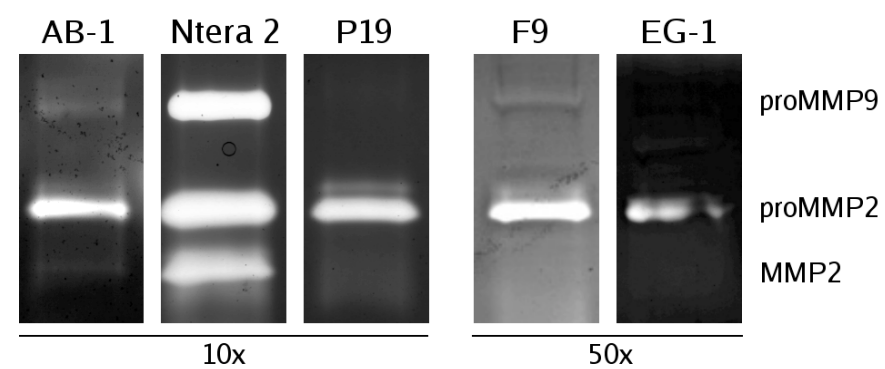

Fig. 2. Zymography. Culture media harvested from AB1 murine embryonic stem cells, EG-1 murine embryonic germ cells, F9 and P19 mouse embryonal carcinoma cells and human embryonal carcinoma cells Ntera-2 were analyzed by gelatin zymography. All the cell lines expressed proMMP-2, although F9 and EG-1 conditioned media had to be concentrated five fold more to detect proteolytic activity. Pro-MMP-9 activity was identified in AB1 and F9 cell lines but with a weak signal, while Ntera-2 produces both pro-MMP-2 and pro-MMP-9 at similarly high levels. Interestingly, the Ntera-2 cell line is the only one which expressed the active form of MMP-2 (Lower molecular weigh band). 
In non-pathological situations, proteolytic activity is strongly regulated to avoid tissue damage. This regulation may appear at the transcriptional or at the translational levels of MMP processing by growth factors or cell-to-cell or cell-to-matrix interactions. Inhibition of the activity of these enzymes can also occur by natural inhibitors called tissue inhibitor of metalloproteinases (TIMP). TIMPs are expressed in a wide variety of cell types and are found in the majority of tissues and corporal fluids. There are four known TIMPs, designated TIMP-1, -2, -3 and -4. TIMPs form non-covalent stoichiometric 1:1 complexes with MMPs or pro-MMPs and inhibit or regulate the enzymatic activity process in this way (Gomez et al., 1997).TIMP-1, -2 and -4 are found in a soluble form, while TIMP3 appears closely attached to the ECM. The pattern of TIMP-4 mRNA expression in brain, heart, ovary and skeletal muscle suggests that this inhibitor is an important regulator of ECM remodeling (Leco et al., 1997). TIMP-2 facilitates the activation of MMP-2, joining pro-MMP-2 (Howard and Banda, 1991) and TIMP1 preferentially forms complexes with proMMP-9 (Wilhelm et al., 1989). TIMP-2 and -3 , but not TIMP-1, are effective inhibitors of MT-MMPs (Bode and Maskos, 2001). The expression of TIMP-2 is constitutive, while TIMP-1 expression is induced by growth factors such as bFGF, PDGF and EGF or cytokines, such as IL-1 and IL6 . The expression of TIMPs and of MMPs is increased by some of these factors, but in the case of TGF- $\beta$, retinoids and erythropoietin, MMP synthesis decreases and TIMP-1 synthesis increases (Clark et al., 1987; Overall, 1994;).

TIMPs carry out several functions. Many of them are associated with their inhibition of MMPs, but they also present functions which are independent of MMP. Regulation of cellular growth (Bertaux et al., 1991), prevention of apoptosis (Lee et al., 2003b) and inhibition of angiogenesis (Seo et al., 2003) stand among these functions. The promoting activity of cellular growth is common, at least to TIMP-1, -2 and -3 and several results point to the fact that they exert this function independently of the inhibition of MMPs (Bertaux et al., 1991; Kikuchi et al., 1997). Other authors have described TIMP-1, -2 and -4 as growth inhibitors in some cell types, among which several carcinomas are found (Guedez et al., 2001; Celiker et al., 2001). Proteolytic activity has been found to be required for the angiogenesis process. New blood vessels formation is necessary for tumor growth and metastasis and it has recently been shown that the ets-1 transcription factor is not only involved in the induction of MMP expression, but it also enhance angiogenesis in metastatic testicular germ cell tumors (Adam et al., 2003).

\section{Growth factors}

Several growth and motility factors have been studied because of their potential relation with tumor development (Mueller et al., 2003; Opdenakker and Van Damme, 2004). These factors can regulate distinct processes involved in invasion, such as cell growth and differentiation, proteolytic activity, cell-cell and cellmatrix adhesion, cell motility and stromal reaction. Insulin-like growth factors (IGFs) and transforming growth factors $\beta$ (TGF- $\beta$ s) are known to participate in the regulation of testicular function and both systems have been related with tumor progression. IGF-I and II are peptide hormones of $\sim 7 \mathrm{kDa}$. Both are synthesized and secreted by many tissues and produce a wide range of responses mainly related to growth and differentiation in several cell lines. They can be transported by blood to distant sites, acting as endocrine hormones. In other cases, they can have local effects acting in a paracrine or autocrine way. Two kinds of receptors for IGFs and six different IGF binding proteins (IGFBP), responsible for the regulation of the IGF system, have been identified (Lowe, 1996; Clemmons, 1998). Both IGF-I and IGF-II are synthesized locally in the testis by Sertoli cells, Leydig cells, germ cells and peritubular cells and the expression of IGF-I is stimulated in vitroby treatments with FSH, LH and GH (Vannelli etal., 1988; Dombrowicz et al., 1992). Both IGF-I and IGF-II participate in the local regulation of testicular function. In the interstitium, IGF-I stimulates testosterone synthesis by Leydig cells (Lin et al., 1986) and in the seminiferous tubules, it has an effect on Sertoli cells, increasing lactate synthesis (Oonk and Grootegoed, 1988) and glucose transport (Oonk et al., 1989), both processes needed for germ cell maintenance. In spermatogonia, IGF-I stimulates DNA synthesis (Söder et al., 1992). It is known that IGF-II participates in embryonic and fetal development and it can enhance the proliferation of spermatogonia in vitro, but its postnatal function is still not clear.

Many observations have shown that IGF-I and -II are involved in cancer pathobiology. They are associated with a higher risk of tumor development and with more invasive behavior of cancer (Rosen and Pollak, 1999). It is known that many oncogenes enhance the expression of IGF system components. In contrast, this system can be inhibited by tumor suppressor genes (Baserga et al., 1997). Other evidence demonstrates the association between the IGF system and cancer progression (Grimberg, 2003). Several studies identify the IGF system as promoter of the expression of many extracellular matrix proteinases, mainly of the MMP group. The IGF-I receptor (IGF-IR) has been recognized as a regulator of MMP-2; this protease is commonly implicated in the degradation of the basal membrane and its up-regulation has been associated with angiogenesis, tumor invasion and metastasis.

Occasionally IGF-I signaling can be conflicting. For example, when the $\mathrm{H}-59$ lung carcinoma cell line is treated with IGF-I at 10 $\mathrm{ng} / \mathrm{ml}$, the synthesis and activation of MMP-2 is enhanced via the PI3-K/Akt signal pathway, but at a higher IGF-I concentration (100 $\mathrm{ng} / \mathrm{ml}$ ), it can inhibit the synthesis of MMP-2 in this cell line via the Raf/ERK pathway. Thus, the final effect of the IGF-IR on MMP-2 activity may depend on other factors, such as ligand availability, which shift the balance toward the activation or the inhibition pathway (Zhang et al., 2004). We observed in Matrigel invasion experiments that treatments with wortmannin, a PI3-K inhibitor, reduces the number of invasive cells of the $\mathrm{P} 19$ embryonal carcinoma cell line by up to $70 \%$ (data not shown), but the mechanism of this inhibition remains unclear. The IGF-IR regulates MT1-MMP expression and so the MMP-2 activation process (Zhang et al., 2003). High levels of circulating IGFs and low levels of IGF Binding Protein 3 (IGFBP-3) have recently been shown to be associated with a higher risk of developing colon, breast, prostate and lung cancer, which are known to produce MMP-7. IGFBP-3 regulates the IGF system, inhibiting the binding of IGF-I to its receptor. The degradation of IGFBP-3 by MMP-7 increases the levels of IGF-I associated with the IGF-IR and consequently the Akt signal pathway is activated, thereby preventing apoptosis and promoting cell survival (Miyamoto et al., 2004). High levels of IGF-IR expression have been found to be related to a more invasive behavior in tumors such as human and canine osteosarcomas (MacEwen et al., 2004) and thyroid carcinomas (Gydee et al., 2004). IGF-IIR is supposed to be a tumor suppressor as it is usually mutated in 
malignant human tumors. It has been demonstrated that downregulation of IGF-IIR enhances growth in cancer cells by maintaining IGF-II, which activates growth promoting signals through IGF-IR (Osipo etal., 2001). In human lung tumors it has been observed that IGF-I, IGF-II and other growth factors are implicated in the upregulation of MMP-2 and MMP-9 activity and in increased cell migration (Bredin et al., 2003). With regard to the mechanism of IGF-I activity, a recent study has shown that $\alpha$-catenin is necessary for IGF-I-induced cell migration in the HCT-8 human colon cancer cell line, while E-cadherin, but not $\alpha$-catenin, is required for the induction of invasion (Andre etal., 2004).

The role of IGF-I in testicular germ cell tumors has been studied. It has been found to be expressed by carcinoma-in-situ cells which also express high levels of IGFBP-5. The latter may regulate the activity of IGF-I and provide a proliferative advantage to the tumor cells (Drescher et al., 1997).

TGF- $\beta$ s are peptide hormones which are also involved in the regulation of tumor development and progression (Akhurst and Derynck, 2001). These factors are homodimers of about $25 \mathrm{kDa}$, consisting of two identical subunits of $12.5 \mathrm{kDa}$ each. These factors acts by means of two types of TGF- $\beta$ receptors (T $\beta R$ ) with Ser/Thr kinase activity. Both T $\beta R$-I and T $\beta R$-II are single-chained integral membrane glycoproteins which form homodimers when they are joined to TGF- $\beta$; the resulting multiprotein complex induces a specific downstream signaling pathway (Massagué, 2000). TGF- $\beta$ has other receptors known as T $\beta R$ III and T $\beta$ R-IV (endoglin), but these receptors do not have kinase activity and act just as accessory proteins which facilitate TGF- $\beta$ signaling (López-Casillas et al., 1993; Sankar et al., 1995; Barbara et al., 1999). TGF- $\alpha$ and TGF- $\beta$ were isolated as two factors which could induce a transformed phenotype in normal rat fibroblasts (de Larco and Todaro, 1978). While TGF- $\alpha$ is a mitogenic factor, TGF$\beta$ acts as a potent growth inhibitor for most cell types (Coffey et al., 1988). Its inhibitory effect on cell proliferation together with its ability to induce apoptosis made TGF- $\beta$ a potential tumor suppressor. This role of TGF- $\beta$ is supported by many observations (Akhurst et al., 1988; Cui et al., 1995); thus, the downstream perturbation of TGF- $\beta$ signaling leads to tumor outgrowth and malignant progression. Mutations in TGFBR2 (which encodes the type II TGF- $\beta$ receptor) are present in tumors from patients with hereditary nonpolyposis colorectal cancer (HNPCC) (Markowitz et al., 1995) and other mutations such as those found in TGFBR1 (which encodes
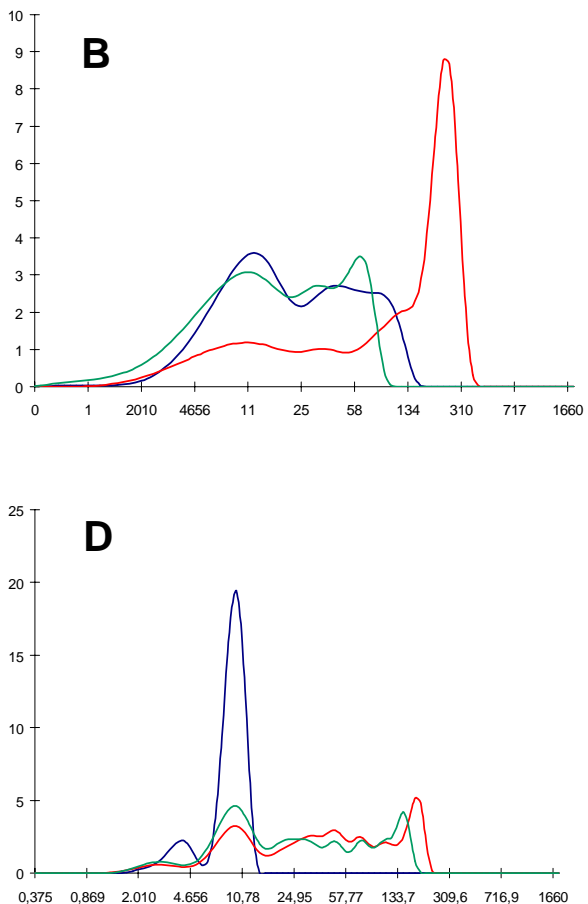

Fig. 3. Fast aggregation assay. Representation of particle diameter $(\mu \mathrm{m})$ vs. relative volume (\%) of aggregates at time $=0$ (blue), time $=30$ min without treatment (red) and time $=30$ min incubating with E-cadherin blocking antibodies (green). The graphics correspond to the $A B 1$ murine embryonic stem cell line (A), the EG-1embryonic germ cell line (B), the murine embryonal carcinoma cell lines F9 (C) and P19 (D) and the human embryonal carcinoma Ntera-2 (E). The human cell line did not aggregate, while murine embryonal carcinomas aggregated, even in the presence of E-cadherin blocking antibodies, suggesting that this cadherin is not the main one responsible for cell-cell adhesion. In contrast, the aggregation capacity of $A B 1$ and EG-1 were sensitive to E-cadherin blocking treatment.

the TGF- $\beta$ type I receptor), MADH2 and MADH4 (encoding Smad2 and Smad4 proteins respectively), have been found in several solid tumors such as pancreas and breast carcinomas (Massagué etal., 2000). Nevertheless, most human tumors do not have any alteration in the TGF- $\beta$ system and retain a correctly functional signaling pathway. However they are still resistant to its growth inhibitory effect, while they conserve and even increase other effects (Calonge and Messagué, 1999; Lehmann et al., 2000).

Moreover, tumors with loss-of-function mutations in the TGF- $\beta$ system have a better prognosis than those which preserve a functional signaling pathway. Members of this last group, despite presenting a lower proliferation rate, show much more invasive behavior and higher metastatic potential (Tsushima et al., 1996; Wikstrom et al., 1998). This was demonstrated by an experiment in which a colon cancer cell line lacking TGF- $\beta$ receptor II expression was transfected with functional TGF- $\beta$ RII cDNA. The result was a reduction in the growth rate and a strong stimulation of the 
invasive and metastatic capacity (Oft et al., 1998). It has also been observed that mammary adenocarcinoma cells treated with TGF$\beta$ undergo an increase in their metastasis formation ability when they are injected in syngenic rats (Welch et al., 1990). These results imply that TGF- $\beta$ can acts as both a tumor suppressor at early stages of tumorigenesis and as invasion stimulator, during advanced stages. The mechanisms employed by TGF- $\beta$ to stimulate tumor invasion include the induction of epithelial to mesenchymal transformation, enhancement of proteinase synthesis and activity, angiogenesis induction and immunosuppressive activities (Akhurst and Derynck, 2001).

The three isoforms of TGF- $\beta(-\beta 1,-\beta 2$ and $-\beta 3)$ have been found to be expressed in the testis. The producer cells and the predominant isoform expressed depend on the stage of the tubule and on the age of the animal (Mullaney and Skinner, 1993; Teerds and Dorrington, 1993). Sertoli cells and peritubular myoid cells express TGF- $\beta 1$ throughout testicular development, while in Leydig cells, it is only detected at fetal and neonatal stages. During these stages, TGF- $\beta 2$ is the main isoform in the testis, located in Sertoli and Leydig cells (Olaso et al., 1997; Teerds and Dorrington, 1993). As for the receptors of TGF- $\beta$, both T $\beta R$-I and -II are expressed by Sertoli and Leydig cells (Le MagueresseBattistoni et al., 1995). T $\beta$ R-Il is also located in spermatogonia (Mullaney and Skinner, 1993). Concerning TGF- $\beta$ functions in the testis, it has been demonstrated that TGF- $\beta$ enhances testosterone production by fetal Leydig cells at low concentrations, although it inhibits this production when present at higher concentrations (Benahmed et al., 1989). TGF- $\beta$ plays a fundamental role in the determination of germ cell number in the seminiferous epithelium, as it reduces their proliferation and induces apoptosis (Prepin and Le Vigouroux, 1997; Olaso et al., 1998). The ECM of the seminiferous tubules is regulated by the interaction of proteinases, proteinase inhibitors and several cytokines, including TGF$\beta$ and tumor necrosis factor alpha (TNF- $\alpha$ ). In Sertoli cells, TGF$\beta$ stimulates the synthesis of proteoglycan (Panthou et al., 1994). Moreover, it reduces proteolytic activity in the ECM, increasing the production of Plasminogen Activator Inhibitor (PAl-1) (Le Magueresse-Battistoni et al., 1998). TGF- $\beta$ also regulates the action of FSH on Sertoli cells (Morera et al., 1992). It has been observed that TGF- $\beta$ has chemoattractant effects on PGCs. For this reason, it is considered to be one of the cytokines implicated in their migration towards the gonadal ridges (De Felici and Pesce, 1994). TGF- $\beta 3$ also plays an important role in the migration of the preleptotene and leptoten spermatocytes through the blood-testis barrier, because it regulates its opening and closing (Lui et al., 2003).

TGF- $\beta 1$ is known to mediate fibroblast to myofibroblast differentiation (Evans et al., 2003) and acts as a fibroblast chemoattractant at the invasion front (De Wever and Mareel, 2003). Myofibroblasts were described as smooth muscle-like fibroblasts (Gabbiani et al., 1971) and their paracrine function has been widely reviewed (Powell et al., 1999). The amount of myofibroblasts found in malignant tumors is much higher than in non-invasive ones and they are localized predominantly at the invasion front (Nakayama et al., 1998). This finding suggests that cytokines expressed by tumor cells, may induce fibroblast to myofibroblast differentiation. The role of myofibroblasts in the invasion process has recently been reviewed (De Wever and Mareel, 2002). It has been shown that factors produced by myofibroblasts, such as tenascin-C and scatter factor/hepatocyte growth factor (SF/HGF) provide proinvasive signals via the Rho family of GTPases in human colon cancer cells (De Wever et al., 2004). The role of epithelial-mesenchymal interaction in the induction of tenascin expression has been reviewed (Ekblom and Aufderheide, 1989).

\section{Adhesion molecules and cytoskeleton}

As mentioned previously, cancer cells have to separate from the primary tumor and migrate through the ECM to reach the circulation before giving rise to metastatic tumors. In this process both cell-cell and cell-matrix adhesion molecules play a key role. The four groups of molecules involved in cell-cell and cell-matrix adhesion are cadherins, integrins, members of the immunoglobulin superfamily and selectins (Pignatelli and Vessey, 1994; Beavon, 2000).

Concerning cell-cell adhesion, the E-cadherin/catenin complex is of particular interest. E-cadherin is a transmembrane glycoprotein of $120 \mathrm{kDa}$ belonging to the cadherin type I superfamily (Nollet et al., 2000), which is made up of calcium-dependent cell-cell adhesion molecules. The adhesion mediated by these molecules is generally homophilic (cadherin-cadherin) and homotypic (between the same cell type), even though there are exceptions, such as the adhesion of epidermal Langerhans cells to keratinocytes or between epithelial cells and T lymphocytes (Tang et al., 1993; Cepek et al., 1994). E-cadherin is made up of an extracellular Nterminal region comprising five subdomains with cadherin-motives tandemly repeated, one transmembrane region and a highly conserved cytoplasmic $\mathrm{C}$-terminal region. The cytoplasmic domain is linked to the actin cytoskeleton via the catenins $\alpha, \beta$ and $\gamma$ (Tucker and Pignatelli, 2000; Nagafuchi and Takeichi, 1988). This interaction suggests that $E$-cadherin has not only a structural function, but it is also implicated in signaling pathways (Chausovsky et al., 2000). Because of its role in the maintenance of normal epithelial architecture, E-cadherin has been identified as a potential tumor and invasion suppressor (Frixen et al., 1991). Furthermore, it has been demonstrated that E-cadherin acts as a growth suppressor via up-regulation of cyclin-dependent kinase p27 (St. Croix et al., 1998). A correlation between cancer aggressiveness and alterations in the E-cadherin/catenin complex has been reported (Bracke et al., 1996; Debruyne et al., 1999). The causal relationship between E-cadherin and in vivo invasion was demonstrated using a transgenic mouse model presenting a high incidence of pancreatic $\beta$-cell adenoma. The loss of E-cadherin mediated cell-cell adhesion induced the adenoma to invasive carcinoma transition, while overexpression of E-cadherin diminished the appearance of the invasive phenotype (Perl et al., 1998).

Using the Fast Aggregation Assay (Bracke et al., 1994) in the presence and absence of specific anti-E-cadherin antibodies, we observed that the embryonic germ cell line EG-1 and the embryonic stem cell line $A B 1$ present aggregation which is sensitive to $E$ cadherin blocking, while the two murine embryonal carcinoma cell lines F9 and P19 still aggregate even in the presence of these antibodies. This result suggests that $E$-cadherin is not the principle factor which is responsible for intercellular adhesion in these cell lines. Rather, another cell-cell adhesion molecule is necessarily involved and is sufficient to maintain aggregate formation ability by itself. We did not obtain aggregates in experiments involving the 

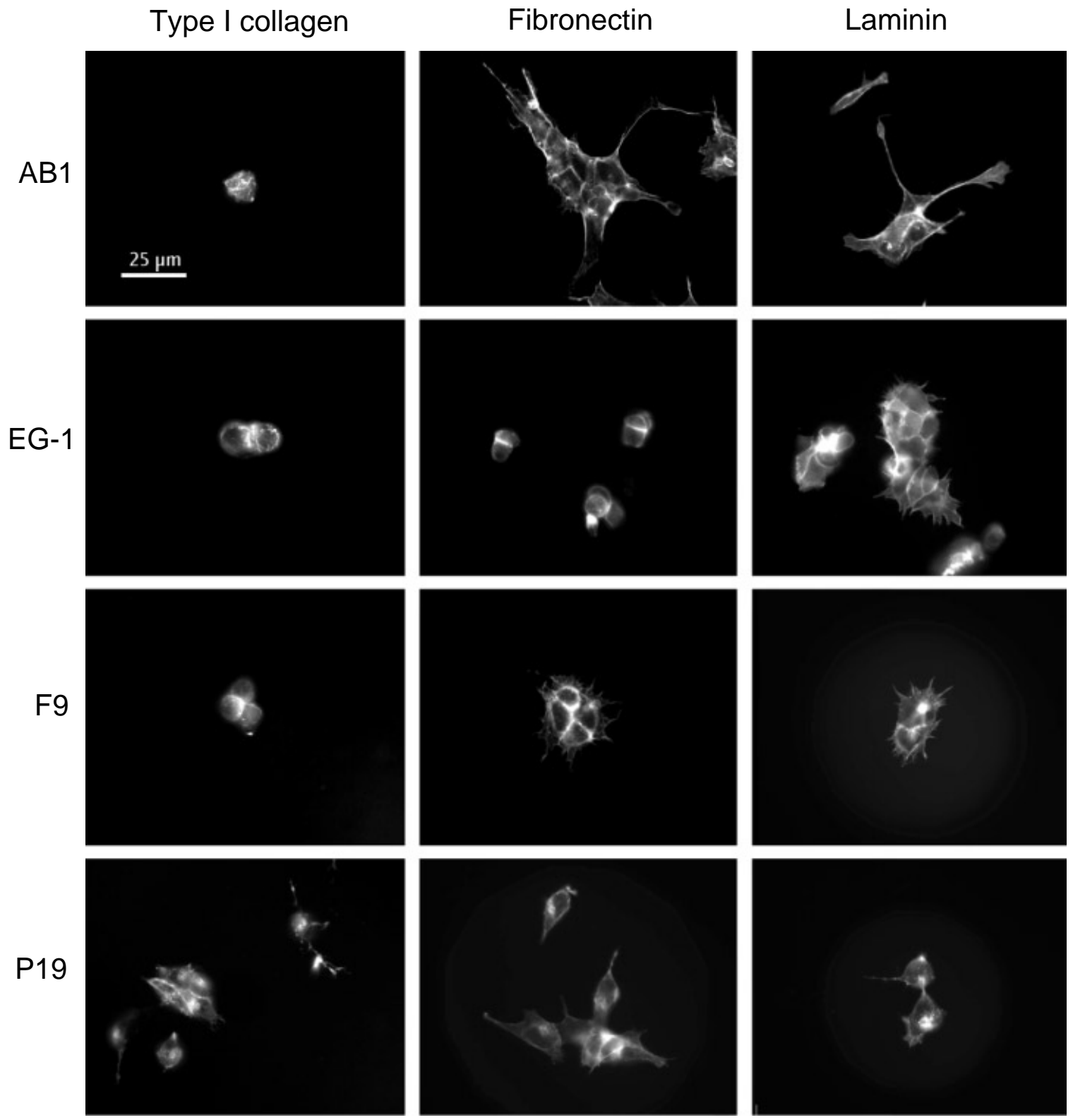

Fig. 4. Actin cytoskeleton stained with Falloidin-FITC in the murine cell lines AB1 (embryonic stem cells), EG-1 (embryonic germ cells), F9 and P19 (both embryonal carcinoma cells), seeded over different substrates. AB1, EG-1 and F9 showed weak adhesiveness to collagen type I presenting a round shape. AB1 and F9 produced fillopodia and lamellipodia on both fibronectin and laminin, while EG-1 presented these only on laminin, showing the same behavior on fibronectin as on collagen type I. P19 had the same adhesiveness on the three substrates and these cells produced extensions in all of them.

human embryonal carcinoma Ntera-2, suggesting that E-cadherin might not be functional in this cell line (Fig. 3). Recently, high levels of a soluble fragment of E-cadherin, resulting from cleavage by MMPs (Noë et al., 2001) produced by cancer or host stromal cells, have been detected in serum from cancer patients and in the conditioned medium of some cancer cell lines (Wheelock et al., 1987). The $80 \mathrm{kDa}$ E-cadherin fragment has been identified as MMP expression promoter in human lung cancer cells (NawrockiRaby et al., 2003).

The switch from E-cadherin to N-cadherin (Cavallaro et al., 2002) in cancer cells has also been described. This switch facilitates the interaction of these cells with the host stromal cells and hence the invasion process (De Wever and Mareel, 2003). $\beta$-catenin is an element of both the E-cadherin/catenin complex (Ozawa etal., 1989) and the Wnt signaling pathway, in which $\beta$-catenin may have a tumorigenic effect (Behrens et al., 1996; Willert and Nusse, 1998). Mutations in $\beta$-catenin phosphorylation sites (Iwao et al., 1998) or in $\beta$-catenin binding sites of the adenomatous polyposis coli (APC) complex (Munemitsu et al., 1995) lead to a nuclear accumulation of $\beta$-catenin in association with lymphocyte enhancer factor/T-cell factor (LEF/TCF). This leads to the formation of a transactivator complex which is involved in the expression of several genes 
A

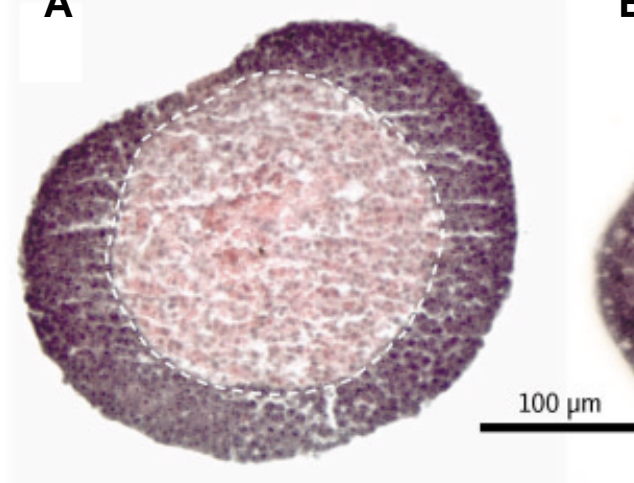

B

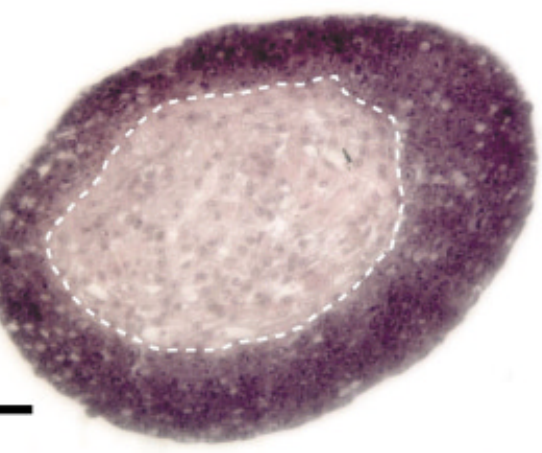

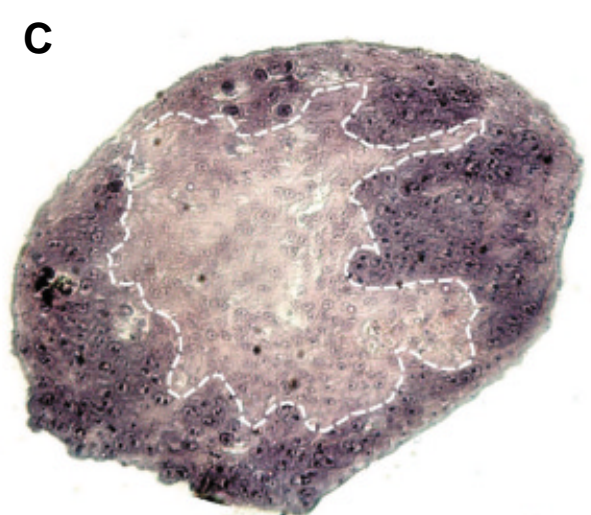

Fig. 5. Chick heart invasion assay. Chick embryonic heart fragments of $0.4 \mathrm{~mm}$ diameter were cocultured with cell aggregates (0.2 mm diameter) of embryonal carcinoma cell lines (P19 and F9) and murine embryonic germ cells (EG-1). Each pair was incubated for 4 days in a shaking incubator at $37^{\circ} \mathrm{C}$ and $70 \mathrm{rpm}$. Then they were fixed with Bouin-Hollander and paraffin-included to make histological sections. Carcinoma and germ cells appear surrounding the heart tissue in the middle. Invasion of carcinoma cells P19 (A) or F9 (B) was not clearly apparent, while EG-1 (C) showed infiltration of germ cells into the heart fragment. Aggregate cultures were fixed in Bouin-Hollande, further proceeded for paraffin sections and stained with Haematoxylin eosin

implicated in cancer development, such as MMP-7 (Crawford et al., 1999), myc (He et al., 1998), cyclin D1 (Lin et al., 2000) and components of the AP-1 transcription complex (Mann et al., 1999).

It has been recently demonstrated that in the testis, both Sertoli and germ cells express $\mathrm{E}$-cadherin, $\mathrm{N}$-cadherin, $\alpha$-catenin, $\beta$ catenin and $\mathrm{p} 120^{\mathrm{ctn}}$. The co-localization and the formation of a complex between $\mathrm{N}$-cadherin and $\beta$-catenin at Sertoli-Sertoli and Sertoli-germ cell adherens junctions in the lower third of the seminiferous epithelium has also been shown. These assays demonstrate that the cadherin/catenin complex is involved in the assembly of functional adherens junctions between Sertoli and germ cells. (Lee et al., 2003a). Despite these results, a study of Ecadherin expression in testis tumors carried out a few years earlier failed to detect E-cadherin on normal germ cells, but it was detected on $18.8 \%$ of studied seminomas and $62.5 \%$ of nonseminomas (Saito et al., 2000). In the same study $\alpha$-catenin was not detected in any of the studied seminomas and in only $25 \%$ of non-seminomas, while $\beta$-catenin was detected in $71.4 \%$ of seminomas and $81.2 \%$ of non-seminomas. E-cadherin has also been identified as an important regulator of PGC migration and homing at gonadal ridges and may modulate PGC development (Di Carlo and De Felici, 2000). N-cadherin has been located on the surface of spermatogonia, primary spermatocytes and endothelial cells, but not on peritubular and Leydig cells (Anderson et al., 1994). Pcadherin is detected in Sertoli cells up to postnatal day 8 but not later, while this cadherin starts to be expressed in peritubular cells at the same time as $\beta$-catenin on days 12 and 15 . The formation of the $\mathrm{P}$-cadherin/ $\beta$-catenin complex in peritubular cell contact areas coincides with the formation of a mature pattern of actin filament organization in these cells (Lin and DePhilip, 1996).

Cell-matrix adhesion proteins are also involved in tumor invasion. The role of integrins in this process has been recently reviewed (Hood and Cheresh, 2002). The ECM has to be degraded to allow sufficient but not excessive cell passage, otherwise cellular traction would be lost (Sheetz et al., 1999). Integrins are not only involved in this traction movement but also take part in signaling pathways which regulate the migration and invasion processes. Integrins are a family of glycoproteins which form heterodimeric receptors for ECM molecules. There are $18 \alpha$-subunits and $8 \beta$ - subunits which can form at least 25 different heterodimers; each of them recognizes a specific set of ligands (van der Flier and Sonnenberg, 2001). Integrins are associated with the actin cytoskeleton via several proteins present in focal contacts (Sastry and Burridge, 2000). Integrins also activate kinases which regulate stress-fiber formation, cell shape and migration. In cancer cells, important alterations in the level of expression of integrins and in their affinity for extracellular matrix ligands have been reported (Mizejewski, 1999).

A study of teratoma induction by injection of normal ES cells and $\beta 1$ integrin-lacking ES cells demonstrated that $\beta 1$ integrin is necessary for teratoma growth and angiogenesis (Bloch et al., 1997). It has also been demonstrated that $\beta 1$ integrin as well as $\mathrm{E}$ - and $\mathrm{N}$ cadherins are involved in MMP-7 induction in cocultures of oral squamous cell carcinoma cell line SCC-25 with human foreskin fibroblasts (Bair et al., 2001). Increased expression of $\beta 1$ and $\alpha 5$ integrins have been found to be associated with lymph node metastasis in non-small lung cancer (Han et al., 2003). We observed that the PGC-derived EG-1 cell line adheres preferentially to laminin and forms lamellipodia on this substrate, while these cells have a round shape and adhere deficiently to fibronectin and collagen type I. This result is consistent with previous observations regarding the affinity of PGCs and spermatogonial stem cells for laminin (García-Castro et al., 1997; Shinohara et al., 1999). In the same experiment, we saw that cells of the F9 embryonal carcinoma cell line have the same behavior as AB1 embryonic stem cells, with round shape and low adhesiveness on collagen type I and formation of prolongations on fibronectin and laminin. P19 cells adhere in a similar way to the three substrates forming prolongations in all of them (Fig. 4). The $\alpha 6 \beta 1$ integrin is known to act as a laminin receptor (Hynes, 1992) and it has also been identified as a mouse spermatogonial stem cell surface marker (Shinohara et al., 1999).

In one of the first papers about the tumor-extracellular matrix interactions in TGCTs it was shown that malignant intratubular germ cells express both $\alpha 6$ and $\beta 1$ integrin subunits and also $\alpha 3$, the loss of which is associated with progression of intratubular neoplasia to invasive seminoma (Timmer et al., 1994). In the rat testis, the $\beta 1$ integrin has been located in peritubular cells, basement membrane, lamina propria and the basal cytoplasm of Sertoli 
cells. The $\alpha 1$ subunit was also detected in peritubular cells and lamina propria. The $\alpha 9$ subunit was only detected in the basement membrane and in peritubular cells (Giebel et al., 1997). The $\beta 1$ subunit has been shown to participate in the regulation of the adherens junctions between Sertoli cells and germ cells (Siu et al., 2003). These junctions have to be disrupted in germ cell malignancies to allow the invasion process. Indeed the $\beta 1$ subunit seems to be downregulated in diffuse seminomas compared with non invasive tumor (Restucci et al., 2000).

Integrins and other cell-surface receptors are involved in the activation of Rho small GTPases (Ren et al., 1999; Ishiguro et al., 2000). The Rho family of GTPases, including Rho, Cdc42 and Rac, can regulate changes in the cytoskeletal organization needed for the initiation of migration (Nobes and Hall, 1995). The role of Rho family GTPases in invasion has already been reviewed (Sander and Collard, 1999). In vivo experiments have demonstrated that Rho proteins are involved in the acquisition of the metastatic phenotype (Del Peso et al., 1997). The induction of Rho activity by lysophosphatidic acid in a hepatoma cell line stimulated migration and invasion through Matrigel in vitro(Wang etal., 2004). Recently, the Rho signaling pathway has also been found to be related to the progression of testicular germ cell tumors, since in these tumors the expression of $R$ hoA and Rho-kinasemRNA is higher than in the normal testicular tissue (Kamai et al., 2002).

\section{Conclusions and perspectives}

The aim of this work is to give an overview of factors potentially implicated in testicular germ cell tumor invasion in order to facilitate future research in this area. Accordingly, we summarize recent advances in cancer invasion research, mentioning specially the implication of tumor-stroma interactions in invasiveness and the role of some factors involved in the invasion process.

Embryonal carcinoma is a type of germ cell tumor which affects mainly adolescents and young adults. They are rare but their incidence has grown fast in recent decades in North America and Europe (Moller and Evans, 2003). Consequently it is of particular interest to understand the mechanisms involved in their invasive process. Given that embryonal carcinoma and the other TGCTs have the PGC-derived carcinoma-in-situ as a common precursor, it would also be interesting to compare the behavior of PGCs and $\mathrm{EC}$ cell lines in in vivo and in vitroinvasion assays. As embryonal carcinoma is a non-seminomatous TGCT, it seems also appropriate to compare them with embryonic stem cells, because of their morphological and biochemical similarities. It is known that several regulators of testicular function, such as IGF and TGF- $\beta$, are involved in tumor progression and invasion promotion. Both of these play a role in the regulation of steroidogenesis and the latter also acts in the stroma attracting fibroblasts and inducing myofibroblast differentiation. However, the role of testicular stroma in the embryonal carcinoma invasion process is still unknown.

The histological analysis of in vivoinduced teratocarcinomas or cocultures of stromal and cancer cell aggregates could be appropriate approaches for the study of stroma-stroma interactions in the testis. We recently performed coculture of precultured heart fragments with aggregates of EG and EC cells in order to determinate the invasiveness of murine EG and EC cells in chick embryonic heart fragments. It was observed that at the fourth day of coculture, the embryonic germ cell line EG-1 is already invading the heart tissue, while the embryonal carcinoma cell lines P19 and F9 still do not present signs of invasion (Fig. 5). Embryonal carcinoma cells can be slowly invasive only when incubated at longer times.

Cell transplantation into seminiferous tubules is another technique which may be useful for studying the invasion process and stroma interactions with the cancer cells in the testis. It consists of microinjecting a cell suspension, to which different substances of interest could be previously added, into the seminiferous tubules by any of the procedures described previously (Ogawa et al., 1997). Some time after the transplantation invasiveness and metastasis can be measured. It would be interesting to analyze the reaction of peritubular myoid cells, as myofibroblasts which are part of the blood-testis barrier (Dym and Fawcett, 1970), in these experiments. These assays will undoubtedly help to acquire a better understanding of the regulatory mechanisms in testicular germ cell tumor invasion.

\section{Acknowledgements}

A. Díez-Torre andU. Silván are Ph.D. students supported by fellowships from the Spanish Ministry for Education and Science and from the University of the Basque Country respectively. This work was supported by a University of the Basque Country Research Grant(\#9/UPV00077.32715304/ 2003) and by FORTIS VERZEKERINGEN, Brussels, Belgium. We are very grateful to Allan Bradley and the Baylor College for providing the AB1 cell line and to Colin Steward for the EG-1 cell line.

\section{References}

ADAM, M., SCHMIDT, D., WARDELMANN, E., WERNERT, N. and ALBERS, P. (2003). Angiogenetic protooncogene ets-1 induced neovascularization is involved in the metastatic process of testicular germ cell tumors. Eur. Urol. 44: 329-336.

AKHURST, R.J. and DERYCK, R. (2001). TGF- $\beta$ signaling in cancer-a double-edged sword. Trends Cell Biol. 11: S44-S51.

AKHURST, R.J., FEE, F. and BALMAIN, A. (1988). Localized production of TGF-beta mRNA in tumor promoter-stimulated mouse epidermis. Nature 331: 363-365.

ALONSO, A., BREUER, B., STEUER, B. and FISCHER, J. (1991). The F9-EC cell line as a model for the analysis of differentiation. Int. J. Dev. Biol. 35: 389-397.

ANDERSSON, A.M., EDVARDSEN, K. and SKAKKEBAEK, N.E. (1994). Expression and localization of $\mathrm{N}$ - and $\mathrm{E}$-cadherin in the human testis and epididymis. Int. J. Androl. 17: 174-180.

ANDRE, F., JANSSENS, B., BRUYNEEL, E., VAN ROY, F., GESPACH, C., MAREEL, M. and BRACKE, M. (2004). Alpha-catenin is required for IGF-I-induced cellular migration but not invasion in human colonic cancer cells. Oncogene23: 1177-1186.

ANDREWS, P.W., DAMJANOV, I., SIMON, D., BANTING, G.S., CARLIN, C., DRACOPOLI, N.C. and FOGH, J. (1984). Pluripotent embryonal carcinoma clones derived from the human teratocarcinoma cell line Tera-2. Differentiation in vivo and in vitro. Lab. Invest. 50: 147-62.

BAIR, E.L., MASSEY, C.P., TRAN, N.L., BORCHERS, A.H., HEIMARK, R.L., CRESS, A.E. and BOWDEN, G.T. (2001). Integrin- and cadherin-mediated induction of the matrix metalloprotease matrilysin in cocultures of malignant oral squamous cell carcinoma cells and dermal fibroblasts. Exp. Cell Res. 270: 259-267.

BARBARA, N.P., WRANA, J.L. and LETARTE, M. (1999). Endoglin is an accessory protein that interacts with the signaling receptor complex of multiple members of the transforming growth factor- $\beta$ family. J. Biol. Chem. 274: 584-594.

BARSKY, S.H., TOGO, S., GARBISA, S. and LIOTTA, L.A. (1993). Type IV collagenase immunoreactivity in invasive breast carcinoma. Lancet 19: 296-297.

BASERGA, R., HONGO, A., RUBINI, M., PRISCO, M. and VALENTINIS, B. (1997). The IGF-I receptor in cell growth, transformation and apoptosis. Biochim. Biophys. Acta 1332: F105-F126.

BASSET, P., BELLOCQ, J.P., WOLF, C., STOLL, I., HUTIN, P., LIMACHER, J.M., PODHAJCER, O.L., CHENARD, M.P., RIO, M.C. and CHAMBON, P. (1990). A novel metalloproteinase gene specifically expressed in stromal cells of breast carcinomas. Nature 348: 699-704. 
BEAVON, I.R.G. (2000). The E-cadherin-catenin complex in tumor metastasis: structure, function and regulation. Eur. J. Cancer36: 1607-1620.

BEHRENS, J., VON KRIES, J.P., KÜHL, M., BRUHN, L., WEDLICH, D., GROSSCHEDL, R. and BIRCHMEIER, W. (1996). Functional interaction of $\beta$ catenin with the transcription factor LEF-1. Nature 382: 638-642.

BENAHMED, M., SORDOILLET, C., CHAUVIN, M.A., DE PERETTI, E. and MORERA, A.M. (1989). On the mechanisms involved in the inhibitory and stimulating actions of transforming growth factor-beta on porcine testicular steroidogenesis: an in vivo study. Mol. Cell. Endocrinol. 67: 155-164.

BERSTINE, E.G., HOOPER, M.L., GRANDCHAMP, S. and EPHRUSSI, B. (1973). Alkaline phosphatase activity in mouse teratoma. Proc. Natt. Acad. Sci. USA70: 3899-903.

BERTAUX, B., HORNEBECK, W., EISEN, A.Z. and DUBERTRET, L. (1991). Growth stimulation of human keratinocytes by tissue inhibitor of metalloproteinases. $J$. Invest. Dermatol. 97: 679-685.

BLOCH, W., FORSBERG, E., LENTINI, S., BRAKEBUSCH, C., MARTIN, K., KRELL, H.W., WEIDLE, U.H., ADDICKS, K. and FÄSSLER, R. (1997). b1 integrin is essential for teratoma growth and angiogenesis. J. Cell. Biol. 139: 265-278.

BODE, W. and MASKOS, K. (2001). Structural studies on MMPs and TIMPs. Methods in Molecular Biology 151: 45-77.

BRACKE, M.E., CHARLIER, C., BRUYNEEL, E.A., LABIT, C., MAREEL, M.M. and CASTRONOVO, V. (1994). Tamoxifen restores the E-cadherin function in human breast cancer MCF-7/6 cells and suppresses their invasive phenotype. Cancer Res. 54: 4607-4609.

BRACKE, M.E., VAN ROY, F.M. and MAREEL, M.M. (1996). The E-cadherin/catenin complex in invasion and metastasis. Attempts to understand metastasis formation. Günthernt U, Birchmeier W (eds). Springer, Berlin, pp 123-161.

BREDIN, C.G., LIU, Z. and KLOMINEK, J. (2003). Growth factor-enhanced expression and activity of matrix metalloproteinases in human non-small cell lung cancer cell lines. Anticancer Res. 23: 4877-4884.

BROOKS, P.C., STRÖMBLAD, S., SANDERS, L.C., VON SCHALSCHA, T.L., AIMES, R.T., STETLER-STEVENSON, W.G., QUIGLEY, J.P. and CHERESH, D.A. (1996). Localization of matrix metalloproteinase MMP-2 to the surface of invasive cells by interaction with integrin $\alpha v \beta 3$. Ce//85: 683-693.

CALONGE, M.J. and MESSAGUÉ, J. (1999). Smad4/DPC4 silencing and hyperactive Ras jointly disrupt transforming growth factor- $\beta$ antiproliferative responses in colon cancer cells. J. Biol. Chem. 274: 33637-33643.

CAVALLARO, U., SCHAFFHAUSER, B. and CHRISTOFORI, G. (2002). Cadherins and the tumor progression: is it all in a switch?. Cancer Lett. 176(2): 123-128.

CELIKER, M.Y., WANG, M., ATSIDAFTOS, E., LIU, X., LIU, Y.E., JIANG, Y., VALDERRAMA, E., GOLDBERG, I.D. and SHI, Y.E. (2001). Inhibition of Wilms' tumor growth by intramuscular administration of tissue inhibitor of metalloproteinase4 plasmid DNA. Oncogene 20: 4337-4343.

CEPEK, K.L., SHAW, S.K., PARKER, C.M., RUSSELL, G.J., MORROW, J.S., RIMM, D.L. and BRENNER, M.B. (1994). Adhesion between epithelial cells and T lymphocytes mediated by E-cadherin and the $\alpha E \beta 7$ integrin. Nature 372: 190-193.

CHAUSOVSKY, A., BERSHADSKY, A.D. and BORISY, G.G. (2000). Cadherinmediated regulation of microtubule dynamics. Nat. Cell. Biol. 2: 794-804.

CLARK, S.D., KOBAYASHI, D.K. and WELGUS, H.G. (1987). Regulation of the expression of tissue inhibitor of metalloproteinases and collagenase by retinoids and glucocorticoids in human fibroblasts. J. Clin. Invest. 80: 1280-1288.

CLEMMONS, D.R. (1998). Role of insulin-like growth factor binding proteins in controlling IGF actions. Mol. Cell. Endocrinol. 140: 19-24.

COFFEY, R.J., BASCOM, C.C., SIPES, N.J., GRAVES-DEAL, R., WEISSMAN, B.E. and MOSES, H.L. (1988). Selective inhibition of growth-related gene expression in murine keratinocytes by transforming growth factor beta. Mol. Cell. Biol. 8: 30883093.

CRAWFORD, H.C., FINGLETON, B.M., RUDOLPH-OWEN, L.A., HEPPNER GOSS, K.J., RUBINFELD, B., POLAKIS, P. and MATRISIAN, L.M. (1999). The metalloproteinase matrilysin is a target of $\beta$-catenin transactivation in intestinal tumors. Oncogene 18: 2883-2891.

CUI, W., FOWLIS, D.J., COUSINS, F.M., DUFFIE, E., BRYSON, S., BALMAIN, A. and AKHURST, R.J. (1995). Concerted action of TGF-beta 1 and its type II receptor in control of epidermal homeostasis in transgenic mice. Genes Dev. 9: 945-955.

DAMJANOV, I. (1991). Pathobiology of human germ cell neoplasia. Recent Results in Cancer Research 123: 1-19.
DE FELICI, M. and PESCE, M. (1994). Growth factors in mouse primordial germ cell migration and proliferation. Prog. Growth Factor Res. 5: 135-143.

DE LARCO, J.E. and TODARO, G.J. (1978). Growth factors from murine sarcoma virus-transformed cells. Proc. Natl. Acad. Sci. USA 75: 4001-4005.

DE WEVER, O. and MAREEL, M. (2002). Role of myofibroblasts at the invasion front. Biol. Chem. 383: 55-67.

DE WEVER, O. and MAREEL, M. (2003). Role of tissue stroma in cancer cell invasion. J. Pathol. 200: 429-447.

DE WEVER, O., NGUYEN, Q.D., VAN HOORDE, L., BRACKE, M., BRUYNEEL, E., GESPACH, C. and MAREEL, M. (2004). Tenascin-C and SF/HGF produced by myofibroblasts in vitro provide convergent pro-invasive signals to human colon cancer cells through RhoA and Rac. FASEB J. 18: 1016-1018.

DEBRUYNE, P., VERMEULEN, S. and MAREEL, M. (1999). The role of the Ecadherin/catenin complex in gastrointestinal cancer. Acta Gastroenterol. Belg. 62: 393-403.

DEL PESO, L., HERNANDEZ-ALCOCEBA, R., EMBADE, N., CARNERO, A., ESTEVE, P., PAJE, C. and LACAL, J.C. (1997). Rho proteins induce metastatic properties in vivo. Oncogene 15: 3047-3057.

DI CARLO, A. and DE FELICI, M. (2000). A role for E-cadherin in mouse primordial germ cell development. Dev. Biol. 226: 209-219.

DOMBROWICZ, D., HOOGHE-PETERS, E.L., GOTHOT, A., SENTE, B., VANHAELST, L., CLOSSET, J. and HENNEN, G. (1992). Cellular localization of IGF-I and IGF-II mRNAs in immature hypophysectomized rat testis and epididymis after in vivo hormonal treatment. Arch Int Physiol Biochim Biophys. 100: 303-308.

DRESCHER, B., LAUKE, H., HARTMANN, M., DAVIDOFF, M.S. and ZUMKELLER, W. (1997). Immunohistochemical pattern of insulin-like growth factor (IGF) I, IGF II and IGF binding proteins 1 to 6 in carcinoma in situ of the testis. Mol. Pathol.50: 298-303.

DUFFY, M.J., O'GRADY, P., DEVANSEY, D., O'SIORAIN, L., FENNELLY, J.J. and LIJNEN, H.R. (1988). Tissue-type plasminogen activator, a new prognostic marker in breast cancer. Cancer Res. 48: 1348-1349.-

DYM, M., FAWCETT, D.W. (1970). The blood-testis barrier in the rat and the physiological compartmentation of the seminiferous epithelium. Biol. Reprod. 3 : 308-326.

EKBLOM, P. and AUFDERHEIDE, E. (1989). Stimulation of tenascin expression in mesenchyme by epithelial-mesenchymal interactions. Int. J. Dev. Biol. 33: 71-79.

EMMERT-BUCK, M.R., EMONARD, H.P., CORCORAN, M.L., KRUTZSCH, H.C., FOIDART, J.-M. and STETLER-STEVENSON, W.G. (1995). Cell surface binding of TIMP-2 and pro-MMP-2/TIMP-2 complex. FEBS Lett. 364: 28-32.

EVANS, M.J. (1972). The isolation and properties of a clonal tissue culture strain of pluripotent mouse teratoma cells. J. Embryol. Exp. Morphol. 28: 163-176.

EVANS, M.J. and KAUFMAN, M.H. (1981). Establishment in culture of pluripotential calls from mouse embryos. Nature292: 154-156.

EVANS, R.A., TIAN, Y.C., STEADMAN, R. and PHILLIPS, A.O. (2003). TGF-b1mediated fibroblast-myofibroblast terminal differentiation-the role of Smad proteins. Exp. Cell Res. 282:90-100.

FOLGUERAS, A.R., PENDÁS, A.M., SÁNCHEZ, L.M. and LÓPEZ-OTíN, C. (2004). Matrix metalloproteinases in cancer: from new functions to improved inhibition strategies. Int. J. Dev. Biol. 48: 411-424.

FRIXEN, U.H., BEHRENS, J., SACHS, M., EBERLE, G., VOSS, B., WARDA, A., LÖCHNER, D. and BIRCHMEIER, W. (1991). E-cadherin-mediated cell-cell adhesion prevents invasiveness of human carcinoma cells. J. Cell Biol. 113: 173-185.

GABBIANI, G., RYAN, G.B. and MAJNO, G. (1971). Presence of modified fibroblasts in granulation tissue and their possible role in wound contraction. Experientia27: 549-550.

GARCÍA-CASTRO, M.I. ANDERSON, R., HEASMAN, J. and WYLIE, C.C. (1997). Interactions between germ cells and extracellular matrix glycoproteins during migration and gonad assembly in the mouse embryo. J. Cel/ Biol. 138: 471-480.

GIEBEL, J., LOSTER, K. and RUNE, G.M. (1997). Localization of integrin beta 1, alpha 1, alpha 5 and alpha 9 subunits in the rat testis. Int. J. Androl. 20(1): 3-9.

GOMEZ, D.E., ALONSO, D.F., YOSHIJI, H. and THORGEIRSSON, U.P. (1997). Tissue inhibitors of metalloproteinases: structure, regulation and biological functions. Eur. J. Cel/ Biol. 74: 111-122.

GRIMBERG, A. (2003). Mechanisms by which IGF-I may promote cancer. Cancer Biol. Ther. 2: 630-635. 
GUEDEZ, L., MC MARLIN, A.J., KINGMA, D.W., BENNETT, T.A., STETLERSTEVENSON, M. and STETLER-STEVENSON, W.G. (2001). Tissue inhibitor of metalloproteinase-1 alters the tumorigenicity of Burkitt's lymphoma via divergent effects on tumor growth and angiogenesis. Am. J. Pathol. 158: 12071215.

GYDEE, H., O'NEILL, J.T., PATEL, A., BAUER, A.J., TUTTLE, R.M. and FRANCIS, G.L. (2004). Differentiated thyroid carcinomas from children and adolescents express IGF-I and IGF-I receptor (IGF-I-R). Cancers with the most intense IGFI-R expression may be more aggressive. Pediatr. Res. 55: 709-715.

HAN, J.-Y., KIM, H.S., LEE, S.H., PARK, W.S., LEE, J.Y. and YOO, N.J. (2003). Immunohistochemical expression of integrins and extracellular matrix preteins in non-small cell lung cancer: correlation with lymph node metastasis. Lung Cancer 41: 65-70.

HE, T.-C., SPARKS, A.B., RAGO, C., HERMEKING, H., ZAWEL, L., DA COSTA, L.T., MORIN, P.J., VOGELSTEIN, B. and KINZLER, K.W. (1998). Identification of C-MYC as a target of the APC pathway. Science 281: 1509-1512.

HEPPNER, K.J., MATRISIAN, L.M., JENSEN, R.A., RODGERS, W.H. (1996). Expression of most matrix metalloproteinase family members in breast cancer represents a tumor-derived host response. Am. J. Pathol. 149: 273-282.

HOEBEN, E., VAN AELST, I., SWINNEN, J.V., OPDENAKKER, G. and VERHOEVEN, G. (1996). Gelatinase A secretion and its control in peritubular and Sertoli cell cultures: effects of hormones, second messengers and inducers of cytokine production. Mol. Cell. Endocrinol. 118: 37-46.

HOOD, J.D. and CHERESH, D.A. (2002). Role of integrins in cell invasion and migration. Nat. Rev. Cancer 2(2):91-100.

HOWARD, E.W. and BANDA, M.J. (1991). Binding of tissue inhibitor of metalloproteinases 2 to two distinct sites on human 72-kDa gelatinase. Identification of a stabilization site. J. Biol. Chem. 266: 17972-17977.

HYNES, R.O. (1992). Integrins: versatility, modulation and signaling in cell adhesion. Cel/69: 11-25.

ISHIGURO, K., KADOMATSU, K., KOJIMA, T., MURAMATSU, H., TSUZUKI, S., NAKAMURA, E., KUSUGAMI, K., SAITO, H. and MURAMATSU, T. (2000). Syndecan-4 deficiency impairs focal adhesion formation only under restricted conditions. J. Biol. Chem. 275: 5249-5252.

IWAO, K., NAKAMORI, S., KAMEYAMA, M., IMAOKA, S., KINOSHITA, M., FUKUI, T., ISHIGURO, S., NAKAMURA, Y. and MIYOSHI, Y. (1998). Activation of the $\beta$-catenin gene by interstitial deletions involving exon 3 in primary colorectal carcinomas without adenomatous polyposis coli mutations. Cancer Res. 58: 1021-1026.

JIANG L.I. and NADEAU, J.H. (2001). 129/Sv mice a model system for studying germ cell biology and testicular cancer. Mamm. Genome. 12: 89-94.

JøRGENSEN, N., RAJPERT-DE MEYTS, E., GRAEM, N., MÜLLER, J., GIWERCMAN, A. and SKAKKEB/EK, N.E. (1995). Expression of immunohistochemical markers for testicular carcinoma in situ by normal human fetal germ cells. Lab. Invest. 72: 223-231.

KAHAN, B.W. and EPHRUSSI, B. (1970). Developmental potentialities of clonal in vitro cultures of mouse testicular teratoma. J Nat/ Cancer Inst. 44: 1015-1036.

KAMAI, T., ARAI, K., TSUJII, T., HONDA, M. and YOSHIDA, K. (2001). Overexpression of RhoA mRNA is associated with advanced stage in testicular germ cell tumor. BJU Int. 87: 227-231.

KIKUCHI, K., KADONO, T., FURUE, M. and TAMAKI, K. (1997). Tissue inhibitor of metalloproteinase 1 (TIMP-1) may be an autocrine growth factor in seleroderma fibroblasts. J. Invest. Dermatol. 108: 281-284.

LE MAGUERESSE-BATTISTONI, B., MORERA, A.M., GODDARD, I. and BENAHMED, M. (1995). Expression of mRNAs for transforming growth factorbeta receptors in the rat testis. Endocrinology 136: 2788-2791.

LEMAGUERESSE-BATTISTONI, B., PERNOD, G., SIGILLO, F., KOLODIE, L. and BENAHMED, M. (1998). Plasminogen activator inhibitor-1 is expressed in cultures rat Sertoli cells. Biol. Reprod. 59: 591-598.

LECO, K.J., APTE, S.S., TANIGUCHI, G.T., HAWKES, S.P., KHOKHA, R., SCHULTZ, G.A. and EDWARDS, D.R. (1997). Murine tissue inhibitor of metalloproteinases-4 (Timp-4): cDNA isolation and expression in adult mouse tissues. FEBS Lett. 401: 213-217.

LEE, N.P.Y., MRUK, D., LEE, W.M. and YAN CHENG, C. (2003a). Is the cadherin/ catenin complex a functional unit of cell-cell actin-based adherens junctions in the rat testis?. Biol. Reprod. 68: 489-508.
LEE, S.J., YOO, H.J., BAE, Y.S., KIM, H.J and LEE, S.T. (2003b). TIMP-1 inhibits apoptosis in breast carcinoma cells via a pathway involving pertussis toxinsensitive G protein and c-Src. Biochem Biophys Res Commun. 312:1196-1201.

LEHMANN, K., JANDA, E., PIERREUX, C.E., RYtOMAA, M., SCHUlZE, A., McMAHON, M., HILL, C.S., BEUG, H. and DOWNWARD, J. (2000). Raf induces TGFbeta production while blocking its apoptotic but not invasive responses: a mechanism leading to increased malignancy in epithelial cells. Genes Dev. 14: 2610-2622.

LEHTONEN E., LAASONEN A. and TIENARI J. (1989). Teratocarcinoma stem cells as a model for differentiation in the mouse embryo. Int. J. Dev. Biol. 33: 105-115.

LIN, L.H. and DEPHILIP, R.M. (1996). Differential expression of placental (P)cadherin in Sertoli cells and peritubular myoid cells during postnatal development of the mouse testis. Anat. Rec. 244(2): 155-164.

LIN, S.-Y., XIA, W., WANG, J.C., KWONG, K.Y., SPOHN, B., WEN, Y., PESTELL, R.G. and HUNG, M.-C. (2000). $\beta$-catenin, a novel prognostic marker for breast cancer: its roles in cyclin D1 expression and cancer progression. Proc. Natt. Acad. Sci. USA 97:4262-4266.

LIN, T., HASKELL, J., VINSON, N. and TERRACIO, L. (1986). Direct stimulatory effects of insulin-like growth factor-I on Leydig cell steroidogenesis in primary culture. Biochem. Biophys. Res. Commun. 137: 950-956.

LOOIJENGA, L.H.J., ZAFARANA, G., GRYGALEWICZ, B., SUMMERSGILL, B., DEBIEC-RYCHTER, M., VELTMAN, J., SCHOENMAKERS, E.F., RODRIGUEZ, S., JAFER, O., CLARCK, J., VAN KESSEL, A.G., SHIPLEY, J., VAN GURP, R.J., GILLIS, A.J. and OOSTERHUIS, J.W. (2003). Role of gain of 12p in germ cell tumor development. APMIS 111: 161-173.

LÓPEZ-CASILLAS, F., WRANA, J. and MASSAGUÉ, J. (1993). Betaglycan presents ligand to the TGF $\beta$ signaling receptor. Cel/73: 1435-1444.

LOWE, W.L.J. (1996). Insulin-like growth factors. Scientific American. Science \& Medicine. pp. 62-71.

LUI, W.Y., LEE, W.M. and CHENG, C.Y. (2003). Transforming growth factor beta3 regulates the dynamics of Sertoli cell tight junctions via the p38 mitogenactivated protein kinase pathway. Biol. Reprod. 68: 1597-1612.

LYNCH, C.C. and MATRISIAN, L.M. (2002). Matrix metalloproteinases in tumorhost cell communication. Differentiation 70: 561-573.

MAC EWEN, E.G., PASTOR, J., KUTZKE, J., TSAN, R., KURZMAN, I.D., THAMM, D.H., WILSON, M. and RADINSKY, R. (2004). IGF-I receptor contributes to the malignant phenotype in human and canine osteosarcoma. J. Cell. Biochem. 92: 77-91.

MANN, B., GELOS, M., SIEDOW, A., HANSKI, M.L., GRATCHEV, A., ILYAS, M., BODMER, W.F., MOYER, M.P. RIECKEN, F.O., BUHR, H.J. and HANSKI, C. (1999). Target genes of b-catenin-T cell-factor/lymphoid-enhancer-factor signaling in human colorectal carcinomas. Proc. Natl. Acad. Sci. USA 96: 16031608.

MARKOWITZ, S., WANG, J., MYEROFF, L., PARSONS, R., SUN, L., LUTTERBAUGH, J., FAN, R.S., ZBOROWSKA, E., KINZLER, K.W., VOGELSTEIN, B. ET AL. (1995). Inactivation of the type II TGF-beta receptor in colon cancer cells with microsatellite instability. Science 268: 1336-1338.

MASSAGUÉ, J. (2000). How cells read TGF- $\beta$ signals. Nat RevMolCel/Biol. 1:169178.

MASSAGUÉ, J., Blain, S.W. and Lo, R.S. (2000). TGFbeta signaling in growth control, cancer and heritable disorders. Cel/ 103: 295-309.

McBURNEY M.W. (1993). P19 embryonal carcinoma cells. Int. J. Dev. Biol. 37: 135140.

McBURNEY, M.W. and ROGERS B.J. (1982). Isolation of male embryonal carcinoma cells and their chromosome replication patterns. Dev. Biol. 89: 503-508.

MITRA, A., CHAKRABARTI, J., CHATTOPADHYAY, N. and CHATTERJEE, A. (2003). Membrane-associated MMP-2 in human cervical cancer. J. Environ. Pathol. Toxicol. Oncol. 22(2): 93-100.

MIYAMOTO, S., YANO, K., SUGIMOTO, S., ISHII, G., HASEBE, T., ENDOH, Y., KODAMA, K., GOYA, M., CHIBA, T. and OCHIAI, A. (2004). Matrix metalloproteinase-7 facilitates insulin-like growth factor bioavailability through its proteinase activity on insulin-like growth factor binding protein 3. CancerRes. 64: 665-671.

MIZEJEWSKI, G.J. (1999). Role of integrins in cancer: survey of expression patterns. Proc. Soc. Exp. Biol. Med. 222: 124-138. 
MOLLER, H. and EVANS, H. (2003). Epidemiology of gonadal germ cell cancer in males and females. APMIS 111: 43-46.

MORERA, A.M., ESPOSITO, G., GHIGLIERI, C., CHAUVIN, M.A., HARTMANN, D.J. and BENAHMED, M. (1992). Transforming growth factor- $\beta 1$ inhibits gonadotropin action in cultured porcine Sertoli cells. Endocrinology 130: 831-836.

MUELLER, M.M, WERBOWETSKI, T. and DEL MAESTRO, R.F. (2003). Soluble factors involved in glioma invasion. Acta Neurochir. 145: 999-1008.

MULLANEY, B.P. and SKINNER, M.K. (1993). Transforming growth factor-beta (beta 1 , beta 2 and beta 3) gene expression and action during pubertal development of the seminiferous tubule: potential role at the onset of spermatogenesis. Mol. Endocrinol. 7: 67-76.

MUNEMITSU, S., ALBERT, I., SOUZA, B., RUBINFELD, B. and POLAKIS, P. (1995). Regulation of intracellular $\beta$-catenin levels by the adenomatous polyposis coli (APC) tumor-suppressor protein. Proc. Natl. Acad. Sci. USA 92: 3046-3050.

NAGAFUCHI, A. and TAKEICHI, M. (1988). Cell binding function of E-cadherin is regulated by the cytoplasmic domain. EMBO J. 7: 3679-3684.

NAKAYAMA, H., ENZAN, H., MIYAZAKI, E., NARUSE, K., KIYOKU, H. and HIROI, M. (1998). The role of myofibroblasts at the tumor border of invasive colorectal adenocarcinomas. Jpn. J. Clin. Oncol. 28: 615-620.

NAWROCKI-RABY, B., GILLES, C., POLETTE, M., BRUYNEEL, E., LARONZE, J.Y., BONNET, N., FOIDART, J.M., MAREEL, M. and BIREMBAUT, P. (2003). Upregulation of MMPs by soluble E-cadherin in human lung tumor cells. Int. J. Cancer. 105(6): 790-795.

NOBES, C.D. and HALL, A. (1995). Rho, Rac and Cdc42 GTPases regulate the assembly of multimolecular focal complexes associated with actin stress fibers, lamellipodia and filopodia. Cel/81: 53-62.

NOË, V., FINGLETON, B., JACOBS, K., CRAWFORD, H.C., VERMEULEN, S., STEELANT, W., BRUYNEEL, E., MATRISIAN, L.M. and MAREEL, M. (2001). Release of an invasion promoter E-cadherin fragment by matrilysin and stromelysin1. J Cell Sci. 114:111-118.

NOLLET, F., KOOLS, P. and VAN ROY, F. (2000). Phylogenetic analysis of the cadherin superfamily allows identification of six major subfamilies besides several solitary members. J. Mol. Biol. 299: 551-572.

OFT, M., HEIDER, K.H. and BEUG, H. (1998). TGFbeta signaling is necessary for carcinoma cell invasiveness and metastasis. Curr. Biol. 8: 1243-1252.

OGAWA, T., ARÉCHAGA, J.M., AVARBOCK, M.R. and BRINSTER, R.L. (1997). Transplantation of testis germinal cells into mouse seminiferous tubules. Int. J. Dev. Biol. 41: 111-122.

OLASO, R., GAUTIER, C., LEVACHER, C., DURAND, P., SAEZ, J. and HABERT, R. (1997). The immunohistochemical localization of transforming growth factor-beta 2 in the fetal and neonatal rat testis. Mol. Cell. Endocrinol. 126: 165-172.

OLASO, R., PAIRSAT, C., BOULOGNE, B., DURAND, P. and HABERT, R. (1998). Transforming growth factor $\beta 1$ and $\beta 2$ reduce the number of gonocytes by increasing apoptosis. Endocrinology 139: 733-740.

OONK, R.B. and GROOTEGOED, J.A. (1988). Insulin-like growth factor I (IGF-I) receptors on Sertoli cells from immature rats and age-dependent testicular binding of IGF-I and insulin. Mol. Cell. Endocrinol. 55: 33-43.

OONK, R.B., JANSEN, R. and GROOTEGOED, J.A. (1989). Differential effects of follicle-stimulating hormone and insulin-like growth factor $I$ on hexose uptake and lactate production by rat Sertoli cells. J. Cell. Physiol. 139: 210-218.

OOSTERHUIS J.W. and LOOIJENGA L.H. (2003). Current views on the pathogenesis of testicular germ cell tumors and perspectives for future research: highlights of the 5th Copenhagen Workshop on Carcinoma in situ and Cancer of the Testis. APMIS 111: 280-289.

OPDENAKKER, G. and VAN DAMME, J. (2004). The countercurrent principle in invasion and metastasis of cancer cells. Recent insights on the role of chemokines. Int. J. Dev. Biol. 48: 519-528.

OSIPO, C., DORMAN, S. and FRANKFATER, A. (2001). Loss of insulin-like growth factor II receptor expression promotes growth in cancer by increasing intracellular signaling from both IGF-I and insulin receptors. Exp. Cell. Res. 264: 388-396.

OVERALL, C.M. (1994). Regulation of tissue inhibitor of matrix metalloproteinase expression. Ann. N. Y. Acad. Sci. 732: 51-64.

OZAWA, M., BARIBAULT, H. and KEMLER, R. (1989). The cytoplasmic domain of the cell adhesion molecule uvomorulin associates with three independent proteins structurally related in different species. EMBO J. 8: 1711-1717.
PANTHOU, P. BARBEY, P., THIEBOT, B. and BOCQUET, J. (1994). Effects of transforming growth factor- $\beta 1$, interleukin- $1 \alpha$ and interleukin- 6 on rat Sertoli cell proteoglycans synthesis. Biochem. Mol. Biol. Int. 34: 603-612.

PERL, A.-K., WILGENBUS, P., DAHL, U., SEMB, H. and CHRISTOFORI, H. (1998). A causal role for $\mathrm{E}$-cadherin in the transition form adenoma to carcinoma. Nature 392: 190-193.

PIGNATELLI, M., VESSEY, C.J. (1994). Adhesion molecules: novel molecular tools in tumor pathology. Hum. Pathol. 25: 849-856.

POLETTE, M., NAWROCKI-RABY, B., GILLES, C., CLAVEL, C. and BIREMBAUT, P. (2004). Tumor invasion and matrix metalloproteinases. Crit. Rev. Oncol. Hematol. 49:179-86.

POWELL, D.W., MIFFLIN, R.C., VALENTICH, J.D., CROWE, S.E., SAADA, J.I. and WEST, A.B. (1999). Myofibroblasts. I. Paracrine cells important in health and disease. Am. J. Physiol. 277: C1-9.

PREPIN, J. and LE VIGOUROUX, P. (1997). Inhibition by TGF-b1 of the in vitro thymulin-stimulated proliferation of gonocytes from fetal rat testes. Reprod. Nutr. Dev. 37: 203-206.

REN, X.D., KIOSSES, W.B. and SCHWARTZ, M.A. (1999). Regulation of the small GTP-binding protein Rho by cell adhesion and the cytoskeleton. EMBOJ. 18: 578585.

RESTUCCI, B., MAIOLINO, P., PAPPARELLA, S. and DE VICO, G. (2000). Expression of b1 integrin in relation to histological features in normal and neoplastic canine testicles. J. Comp. Pathol. 123: 164-170.

ROELOFS, H., MOSTERT, M.C., POMPE, K., ZAFARANA, G., VAN OORSCHOT, M., VAN GURP, R.H.J.L.M., GILLIS, A.J.M., STOOP, H., BEVERLOO, B., OOSTERHUIS, J.W., BOKEMEYER, C. and LOOIJENGA, L.H.J. (2000). Restricted $12 p$ amplification and RAS mutation in human germ cell tumors of the adult testis. Am. J. Pathol. 157: 1155-1166.

ROSEN, C.J. and POLLAK, M. (1999). Circulating IGF-I: New perspectives for a new century. Trends Endocrinol. Metab. 10: 136-141.

SAITO, T., KATAGIRI, A., WATANABE, R., TANIKAWA, T., KAWASAKI, T., TOMITA, Y. and TAKAHASHI, K. (2000). Expression of E-cadherin and catenins on testis tumor. Urol. Int. 65: 140-143.

SANDER, E.E. and COLLARD, J.G. (1999). Rho-like GTPases: Their role in epithelial cell-cell adhesion and invasion. Eur. J. Cancer35(9): 1302-1308.

SANKAR, S., MAHOOTI-BROOKS, N., CENTRELLA, M., MC CARTHY, T.L. and MADRI, J.A. (1995). Expression of transforming growth factor $\beta$ type III receptor in vascular endothelial cells increases their responsiveness to transforming growth factor $\beta 2$. J. Biol. Chem. 270: 13567-13572.

SASTRY, S.K. and BURRIDGE, K. (2000). Focal Adhesion: a nexus for intracellular signaling and cytoskeletal dynamics. Exp. Cell. Res. 261: 25-36.

SATO, T., IWAI, M., SAKAI, T., SATO, M., SEIKI, M., MORI, Y. and ITO, A. (1999). Enhancement of membrane-type 1-matrix metalloproteinase (MT1-MMP) production and sequential activation of progelatinase $A$ on human squamous carcinoma cells co-cultures with human dermal fibroblasts. Br. J. Cancer80: 1137-1143.

SEO, D.W., LI, H., GUEDEZ, L., WINGFIELD, P.T., DIAZ, T., SALLOUM, R., WEI, B.Y. and STETLER-STEVENSON, W.G. (2003). TIMP-2 mediated inhibition of angiogenesis: an MMP-independent mechanism. Cel/114: 171-180.

SHEETZ, M.P., FELSENFELD, D., GALBRAITH, C.G. and CHOQUET, D. (1999). Cell migration as a five-step cycle. Biochem. Soc. Symp. 65: 233-243.

SHINOHARA, T., AVARBOCK, M.R. and BRINSTER, R.L. (1999). $\beta 1$ - and $\alpha 6$-integrin are surface markers on mouse spermatogonial stem cells. Proc. Natl. Acad. Sci. USA 96: 5504-5509.

SIU, M.K., MRUK, D.D., LEE, W.M. and CHENG, C.Y. (2003). Adhering junction dynamics in the testis are regulated by an interplay of beta 1 -integrin and focal adhesion complex-associated proteins. Endocrinology 144(5): 2141-2163.

SKAKKEB/EK, N.E., BERTHELSEN, J.G., GIWERCMAN, A. and MULLER, J. (1987). Carcinoma-in-situ of the testis: possible origin from gonocytes and precursor of all types of germ cell tumors except spermatocytoma. Int. J. Androl. 10: 19-28.

SLONGO, M.L., ZAMPIERI, M. and ONISTO, M. (2002). Expression of matrix metalloproteases (MMP-2, MT1 -MMP) and their tissue inhibitor (TIMP-2) by rat sertoli cells in culture: implications for spermatogenesis. Biol. Chem. 383: 235-239.

SÖDER, O., BANG, P., WAHAB, A. and PARVINEN, M. (1992). Insulin-like growth factors selectively stimulate spermatogonial, but not meiotic, deoxyribonucleic acid synthesis during rat spermatogenesis. Endocrinology 131: 2344-2350. 
SOLTER, D., SKREB, N. and DAMJANOV, I. (1970). Extrauterine growth of mouse egg-cylinders results in malignant teratoma. Nature 227: 503-504.

ST CROIX, B., SHEEHAN, C., RAK, J.W., RLORENES, V.A., SLINGERLAND, J.M. and KERBEL, R.S. (1998). E-cadherin dependent growth suppression is mediated by the cyclin-dependent kinase inhibitor p27 (KIP1). J. Cel/ Biol. 142: 557571.

STEVENS, L.C. (1970). Environmental influence on experimental teratocarcinogenesis in testes of mice. J. Exp. Zool. 174: 407-14.

STEVENS, L.C. and HUMMEL, K.P. (1957). A description of spontaneous congenital testicular teratomas in strain 129 mice. J. Natt. Cancer Inst. 18: 719-747.

STEWART, C.L., GADI, I. and BHATT, H. (1994) Stem cells from primordial germ cells can re-enter the germ line. Dev. Biol. 161: 626-628.

STRONGIN, A.Y., COLLIER, I., BANNIKOV, G., MARMER, B.L., GRANT, G.A. and GOLDBERG, G.I. (1995). Mechanism of cell surface activation of 72-kDa type IV collagenase. J. Biol. Chem. 270: 5331-5338.

TANG, A., AMAGAI, M., GRANGER, L.G., STANLEY, J.R. and UDEY, M.C. (1993). Adhesion of epidermal Langerhans cells to keratinocytes mediated by $\mathrm{E}$ cadherin. Nature 361: 82-85.

TEERDS, K.J. and DORRINGTON, J.H. (1993). Localization of transforming growth factor beta 1 and beta 2 during testicular development in the rat. Biol. Reprod. 48: 40-45.

THORPE, S.M., ROCHEFORT, H., GARCIA, M., FREISS, G., CHRISTENSEN, G., KHALAF, S., PAOLUCCI, F., PAU, B., RASMUSSEN, B.B. and ROSE, C. (1989). Association between high concentrations of Mr 52,000 cathepsin D and poor prognosis in primary human breast cancer. Cancer Res. 49: 6008-6014.

TIMMER, A., OOSTERHUIS, J.W., SCHRAFFORDT, K.H., SLEIJFER, D.T., SZABO, B.G. and TIMENS, W. (1994). The tumor microenvironment: possible role of integrins and the extracellular matrix in tumor biological behavior of intratubular germ cell neoplasia and testicular seminomas. Am. J. Pathol. 144(5): 10351044.

TSUSHIMA, H., KAWATA, S., TAMURA, S., ITO, N., SHIRAI, Y., KISO, S., IMAI, Y., SHIMOMUKAI, H., NOMURA, Y., MATSUDA, Y. and MATSUZAWA, Y. (1996). High levels of transforming growth factor beta 1 in patients with colorectal cancer: association with disease progression. Gastroenterology 110: 375-382.

TUCKER, E.L. and PIGNATELLI, M. (2000). Catenins and their association proteins in colorectal cancer. Histol. Histopathol. 15: 251-260.

URIA, J.A., STAHLE-BACKDAHL, M., SEIKI, M., FUEYO, A. and LOPEZ-OTIN, C.
(1997). Regulation of collagenase-3 in human breast carcinomas is mediated by stroma-epithelial cell interactions. Cancer Res. 57: 4882-4888.

VAN DER FLIER, A. and SONNENBERG, A. (2001). Function and interactions of integrins. Cell Tissue Res. 305: 285-298.

VANNELLI, B.G., BARNI, T., ORLANDO, C., NATALI, A., SERIO, M. and BALBONI, G.C. (1988). Insulin-like growth factor-I (IGF-I) and IGF-I receptor in human testis: an immunohistochemical study. Fertil Steril. 49: 666-669.

WANG, D.S., DOU, K.F., LI, K.Z. and SONG, Z.S. (2004). Enhancement of migration and invasion of hepatoma cells via a Rho GTPase signaling pathway. World J. Gastroenterol. 10(2): 299-302.

WELCH, D.R., FABRA, A. and NAKAJIMA, M. (1990). Transforming growth factor beta stimulates mammary adenocarcinoma cell invasion and metastatic potential. Proc. Natl. Acad. Sci. USA 87: 7678-7682.

WHEELOCK, M.J., BUCK, C.A., BECHTOL, K.B. and DAMSKY, C.H. (1987). Soluble 80-kDa fragment of cell-CAM 120/80 disrupts cell-cell adhesion. J. Cell. Biochem. 34: 187-202.

WIKSTROM, P., STATTIN, P., FRANCK-LISSBRANT, I., DAMBER, J.E., BERGH, A. (1998). Transforming growth factor beta1 is associated with angiogenesis, metastasis and poor clinical outcome in prostate cancer. Prostate 37: 19-29.

WILHELM, S.M, COLLIER, I.E., MARMER, B.L., EISEN, A.Z., GRANT, G.A. and GOLDBERG, G.I. (1989). SV40-transformed human lung fibroblasts secrete a 92-kDa type IV collagenase which is identical to that secreted by normal human macrophages. J. Biol. Chem. 264: 17213-17221.

WILLERT, K. and NUSSE, R. (1998). $\beta$-catenin: a key mediator of Wnt signaling. Curr. Opin. Genet. Dev. 8: 95-102.

ZAFARANA, G., GILLIS, A.J.M., VAN GURP, R.J.H.L.M., OLSSON, P.G., ELSTRODT, F., STOOP, H., MILLAN, J.L., OOSTERHUIS, J.W. and LOOIJENGA, L.H. (2002). Coamplification of DAD-R, SOX5 and EKI1 in human testicular seminomas, with specific overexpression of DAD-R, correlates with reduced levels of apoptosis and earlier clinical manifestation. Cancer Res. 62: 1822-1831.

ZHANG, D., BAR-ELI, M., MELOCHE, S. and BRODT, P. (2004). Dual regulation of MMP-2 expression by the type 1 insulin-like growth factor receptor: the phosphatidylinositol 3-kinase/Akt and Raf/ERK pathways transmit opposing signals. J. Biol. Chem. 279(19): 19683-19690.

ZHANG, D., SAMANI, A.A. and BRODT, P. (2003). The role of the IGF-I receptor in the regulation of matrix metalloproteinases, tumor invasion and metastasis. Horm. Metab. Res. 35: 802-808. 